McInnes, R.J., Hollins Martin, C.J, McArthur, J. (in press). Midwifery continuity of carer: developing a realist evaluation framework to evaluate the implementation of strategic change in Scotland Midwifery. Midwifery. 66 (2018): 103-110.

DOI.org/10.1016/j.midw.2018.07.007

\title{
Midwifery continuity of carer: developing a realist evaluation framework to evaluate the implementation of strategic change in Scotland
}

\begin{abstract}
Midwifery continuity of carer (MCC) models result in better clinical outcomes for women and offer midwives a superior way of working when compared to other models of maternity care. Implementing a MCC model, a key recommendation of the Scottish Government Maternity and Neonatal Strategy Best Start, requires significant restructuring of maternity services and changes to midwives' roles. Careful evaluation is therefore required to monitor and understand how the policy affects care providers and users. Realist evaluation is an appropriate methodology for evaluating programmes of change set within complex social organisations, such as health services, and can help to understand variations in outcomes and experiences. This paper presents the approach taken using the principles of realist evaluation to identify key programme theories, which then informed an evaluation framework and a midwives' evaluation tool. The comprehensive survey-tool developed for midwives has the potential to be used more widely to evaluate comparable strategic change in this area.
\end{abstract}

\section{Introduction}

There is good quality evidence that a midwifery continuity of carer (MCC) model has better outcomes for women and babies (Homer et al., 2017; Sandall et al., 2016a); including lower rates of preterm birth, induction of labour and intra-partum interventions and higher rates of spontaneous vaginal births and breastfeeding. MCC also offers a better working environment for midwives (Dixon et al., 2017; Fenwick et al., 2017). Various formats of MCC models have been successfully implemented in a number of countries such as New Zealand (Dixon et al., 2017; Gilkison et al., 2015); Australia (Fenwick et al., 2017; Newton et al., 2016) and Denmark (Jepsen et al., 2017; Burau and Overgaard, 2015). Implementing a MCC model tailored to the local context is a key recommendation of the Scottish Government (SG) Maternity and Neonatal Strategy called Best Start (Scottish Government, 2017). However, this requires significant restructuring of maternity services and changes to midwives' roles. It is therefore important to undertake careful evaluation to monitor and understand the 
process and effects of the policy on care providers and users and to ensure the continued provision of high quality midwifery care. Realist evaluation (Pawson and Tilley, 1997) is recognised as an appropriate methodology for evaluating programmes of change set within complex social organisations, such as health services, and can help to understand variations in outcomes and experiences. This paper presents the approach taken to develop a realist evaluation framework to evaluate the implementation of MCC in one Scottish health board.

\section{Background}

Good quality midwifery is underpinned by a philosophy of holistic care that optimizes biopsychosocial and cultural processes and strengthens women's capabilities (Renfrew et al., 2014). Quality provision also requires healthy midwives who have good professional and interpersonal skills. There is empirical evidence that midwives working in caseload models experience greater job satisfaction (Jepsen et al., 2017; Newton et al., 2016) and less stress and burnout (Dixon et al., 2017; Fenwick et al., 2017; Newton et al., 2016). MCC models have been successfully implemented in a number of countries, in different settings and structured in different ways; for example individual caseload midwifery versus a team approach such as midwifery group practice. The Australian Government maternity services reform in 2010 allowed increased opportunities for caseload midwives to provide continuity for 35-45 women per year usually from a primary midwife in partnership with a colleague. However, the expansion of MCC has been slow with only an estimated $10 \%$ of women having a known midwife (Fenwick et al., 2017; Newton et al., 2016; Sidebotham et al., 2015, Haines et al., 2015). In New Zealand midwives can work in a hospital or a community setting or a combination of both. The majority of community-based midwives in New Zealand are self-employed as Lead Midwife Carers where they are contracted by the Ministry of Health to provide care to a caseload of around 40-50 women every year (Dixon et al., 2017; Young 2015; Gilkison et al., 2015). Midwife-led practice has been the standard model in Denmark since midwifery was authorised 300 years ago. The model is either team or caseload midwifery with a standard caseload of around 60 women a year. Caseload midwifery has become increasingly popular with $61 \%$ of public maternity units offering it for some women (Jepsen et al., 2017; Jepsen et al., 2016; Bureau and Overgaard, 2015). One-to-One Midwifery has provided caseload midwifery in the Wirral area of North West England since 2010 and West Cheshire since 2014 (http://www.onetoonemidwives.org) with midwives working autonomously in small teams but being commissioned by the NHS to provide care in their area. 
The evidence of impact of MCC models on midwives' work-life balance is not consistent: one Australian study identified no difference in emotional and professional well-being between caseload and non-caseload midwives (Fenwick et al., 2017), whilst another Australian study examining midwifery group practice reported midwives struggling to manage working hours with the commitment of being 'on call' (Collins et al., 2010). There is evidence from a United Kingdom (UK) study that support from management to create work-life balance can be protective against burnout (Yoshida and Sandall, 2013).

Maternity service provision varies across the UK, however the majority of women are cared for in National Health Service (NHS) settings where care is considered to be fragmented around buildings and locations (Sandall et al., 2016b). Location of care tends to be determined by stage of childbearing and/or on maternal medical or obstetric risk factors. Evaluation of the current UK model of midwifery through the Royal College of Midwives (RCM) 'Caring for you survey' (RCM, 2016) indicated high levels of stress, work pressures, and increasing workload among midwives working in a range of maternity care settings. This might suggest that changes to the work environment would be welcome, however, workplace changes can be stressful, particularly if there is perceived lack of control or involvement (Health and Safety Executive (HSE), undated) and while a new model may appear to be beneficial, the upheaval required to deliver it may impact negatively if the workforce is already stressed and overworked. Therefore, any service reorganisation should be monitored closely to protect high quality care and ensure a positive experience for both midwives and women.

Historically implementation of MCC in the UK has varied by type of model, context, target population, eligibility and sustainability. Those implemented in the 1990s were situated within the predominant obstetric model of maternity care, which appeared to create a conflict of beliefs and philosophies (Stevens and McCourt 2002) and often resulted in a poor experience for MCC midwives (Stevens and McCourt, 2002 and anecdotal reports). Evaluation of a previous attempt to implement a MCC model in some parts of this health board identified higher levels of maternal satisfaction and similar clinical outcomes in the caseload model compared to conventional care (Meadows Report, 1998). However, there were also challenges similar to those reported by Stevens and McCourt (2002), including increased stress and burnout for midwives and issues with recruitment and retention in 
these locations. Some of these experiences inform the current local narrative about MCC, such as concerns about work-life balance, control, professional support and sustainability.

Evidence from the UK and other countries indicates that successful implementation of MCC requires initial funding and support (Dawson et al., 2016, Stevens and McCourt, 2002), involvement and negotiation between midwives and management (Burau and Overgaard, 2015), and having midwives who are interested and available to work in the model (Dawson et al., 2016). Ability to conceptualise change and good midwifery leadership is also important for enabling midwives to contribute to the change (Sidebotham et al., 2015). A properly designed model that provides on-going management support, effective back up and cover (Stevens and McCourt, 2002), flexible working (Fereday and Oster, 2010) and an appropriate caseload size (Jepsen et al., 2016) have been shown to help prevent stress and burn out and thus be more sustainable. Experiences of implementing the Midwife Development Unit in Glasgow, which aimed to improve continuity of care, highlighted the importance of involving midwives in the change (Turnbull et al., 1995), which is also reflected in more recent research from other countries such as Denmark and Australia (Burau and Overgaard, 2015; Sidebotham et al., 2015). It is therefore important to ensure that midwives have an opportunity to shape how services are developed in their practice area.

This paper describes in detail the development of a theory-led evaluation framework to monitor the impact of service reorganisation and provide opportunities for midwives to contribute to the implementation of the Scottish MCC model known as 'Best Start' (SG, 2017). It focuses in more detail on the first element of that framework: the development of a midwives' survey. Future elements will include collection of routine data to identify outcomes and separate surveys of women and student midwives.

\section{Aim}

To use a realist evaluation approach to develop an evidence-informed evaluation framework to monitor the effects of service reorganisation and enable midwives to contribute to the implementation of the 'Best Start' MCC model in one health board area.

\section{Objectives}


1. Conduct informal discussions with midwives in a range of settings to scope practice experiences, opinions about the new model, identify key concerns and document the current narrative in relation to context and MCC.

2. Conduct stakeholder interviews to elicit their opinions on policy drivers, measures of success, resources required and available, potential challenges and possible mechanisms which might relate to outcomes.

3. Conduct a literature review to identify factors relating to successful or unsuccessful implementation and continuation of MCC models.

4. Develop programme theories for future testing

5. Map programme theories to framework of high quality midwifery care (Renfrew et al., 2014)

6. Review the literature for pre-validated scales and questions which relate to the domains of high quality midwifery care and to the programme theories identified in preceding steps.

7. Develop an evidence informed evaluation tool designed to scope opinions, current context and personal, professional and psychosocial variables and engage midwives with the change.

\section{Methods}

The principles of realist evaluation (Pawson and Tilley, 1997) were used to develop the evaluation of the implementation of the MCC model. Realist evaluation is a theory-driven approach that places emphasis on understanding the context within which an intervention takes place and aims to understand how, rather than if, a programme or intervention works. Implementing a MCC model fits with Pawson and Tilley's (1997) conceptualisation of 'social programmes', which they describe as initiatives that seek to change existing processes and involves the interaction between individuals and the institution within which they operate. The MCC model is, by its nature, a complex intervention, set within large social organisations, involving a range of different individuals who will have diverse beliefs and behaviours and will therefore respond differently to the model. Understanding how the intervention, the setting and the individuals interact to give particular outcomes is at the root of realist evaluation and can help to explain why outcomes vary when interventions are replicated in different contexts. 
Realist evaluation examines context, mechanism and outcome (CMO) configurations to provide detailed answers to the question of ' $w$ hy a programme works, for whom and in what circumstances?' (Pawson and Tilley, 1997). The preliminary focus in a realist evaluation is the identification of underpinning theories that inform the $\mathrm{CMO}$ configurations, which should be drawn from a combination of literature review, stakeholder interviews and discussions with key informants (Funnell and Rogers 2011). A challenge for researchers can be delineating context and mechanisms (Dalkin et al., 2015; Porter, 2015) and subsequently disaggregating the concept of mechanisms. There are a number of theoretical approaches to the latter; however for the purposes of this framework Dalkin et al.'s (2015) critical analysis of realist evaluation has been influential. They differentiate mechanisms into resources and reasoning and argue that intervention resources are introduced in a context, in a way that enhances a change in reasoning. This, they suggest alters the behaviour of participants, which in turn leads to outcomes.

The literature review focussed on how MCC models have been implemented and sustained in both UK and international contexts and on the perspective and experience of midwives rather than on clinical outcomes for women. Four stakeholder interviews with key policy makers within the organisation were conducted along with informal discussions with midwives in a range of settings focusing on their opinions of the proposed MCC model and their experiences with different models of midwifery care.

These initial stages build the underpinning programme theories and identify $\mathrm{CMO}$ configurations: these are propositions stating what it is about a programme which works for whom in what circumstances. Developing a 'conjectured' CMO configuration is the starting point and the 'refined' CMO configuration emerges following data analysis (Pawson and Tilley, 1997). The conjectured CMO configuration underpinning the MCC evaluation framework, which takes account of Dalkin et al.'s (2015) understanding of resource and reasoning mechanisms is outlined in Table 1 and formed the basis for study design for the pre/post implementation evaluation of the MCC model.

The initial literature review and stakeholder engagement were then mapped to the essential components required for the provision of high quality midwifery care, as recognised in an evidence-based framework developed by Renfrew et al. (2014). The framework identifies five components of high quality midwifery care: practice, care organisation, care providers, 
philosophy and values, all of which are relevant to the contextual elements of a realist evaluation. This helped to identify in more detail the recommended care associated with MCC models and appropriate data collection strategies for the evaluation. Further examination of the literature was undertaken to source any pre-validated scales or questions that could be used in the evaluation (Table 2).

\section{Developing the midwives' survey tool}

The first stage of the evaluation has seen the development of the midwives' survey tool. In addition to the programme theories (Table 1 ) and elements of high quality midwifery care (Table 2), during discussions with key informants (clinical midwives) some resistance to the implementation of the MCC model was identified, with much of the debate highlighting concerns about how changes will impact on their working lives. Therefore, a number of contextual elements were considered relevant for inclusion in the survey: current professional role and context; travel and future preferences; skill or experience updates needed; health and wellbeing (given some anxiety about the change) and a sense of empowerment of working in a midwifery continuity model of care.

\section{Identifying validated measures}

A range of potential scales and questions were discussed within the research team and those deemed to be most relevant were incorporated in a first draft questionnaire. Permission to use these scales and questions was sought from authors. Validated scales and questions included in the survey are outlined in Table 3.

In addition, the survey tool includes a question on experiences and preference for different types of continuity of carer developed from descriptions in the Cochrane review (Sandall et al., 2016a) and a series of continuity statements (Section B of survey) developed from the literature review and informal conversations with midwives. Additional free text questions were included to elicit thoughts about the proposed change, e.g. opportunities or challenges, concerns, skills or experiences required and anticipated impact on personal life or work-life balance. Wording for the free text questions was adapted from a study that explored midwives opinions and experiences following the introduction of a midwifery group practice caseload model of care (Collins et al., 2010).

Testing 
The early version of the survey tool (Version 1 ) was tested within the research team to assess utility for the evaluation (two clinical midwives, one academic midwife and one other research team member). Following refinements, Version 2 was circulated to a small number of practising midwives and the NHS Lothian Midwife Research Champions Group, which enabled the survey to be further developed to include a more succinct introduction, more practice relevant questions and, in relation to 'continuity statements', a more balanced approach to positive and negative options. This updated Version 3 was used to populate the on-line survey tool (NOVI), which was further tested to ensure logical survey architecture.

Feedback following testing indicated that the tool was acceptable and although respondents indicated that it could take 30-40 minutes to complete they could see the value of the different components. It is acknowledged that the length of the survey could be seen as a barrier to its completion. Options such as providing a unique log-in allowing participants to return and complete later were considered, however, during testing participants stressed the importance of ensuring absolute anonymity and this system might act as a barrier. If response rates are low a shorter survey collecting less data but from more individuals could be considered. The final Version 4 (Appendix 1) comprises of questions that ask about: (1) current role, location and travel, (2) models of midwifery care, (3) attitudes to professional role, values and philosophies, (4) demographics, and (5) quality of life and wellbeing.

\section{Discussion}

Significant restructuring of the maternity services and substantial changes to the midwives' role are required for implementation of the Midwifery Continuity of Carer (MCC) model, as recommended by Best Start (SG, 2017) and to some extent for implementation of NHS England's Better Births maternity review (NHS England, 2017). For implementation to be successful, careful service evaluation and monitoring are required. There is growing recognition of the need to build evaluation into delivery of public policy to monitor the progress of change, how it might be impacting on health and health inequalities, and to highlight unintended consequences (Haynes et al., 2012, NHS Scotland 2017). Furthermore, monitoring and testing to find out what does or does not work will enable practice to be adapted to optimise outcomes (Haynes et al., 2012).

Evaluating service reorganisation or policy implementation, such as the Best Start (SG, 2017), is a complex process, partly due to the involvement and perspectives of different stakeholders who might focus on different outcomes and the impact on individuals and 
professional practices (Mackenzie et al., 2007). Further complexity relates to variation in pre-existing local services and how a national policy might be implemented at a local level (Mackenzie et al., 2007), furthermore the Best Start policy (SG, 2017) emphasises the need to tailor services to suit local context. A realist evaluation (Pawson and Tilley, 1997) approach provides a suitable methodology to develop a framework for evaluation as it supports the identification of programme theories that may be relevant to understand the context, mechanisms and outcomes relevant for inclusion in data collection instruments.

Despite the evidence that MCC is a better model for midwives and for women, midwives express concerns about how changes will impact on their working lives. Other research exploring the process of implementing new models of midwifery care (Turnbull et al., 1995; Burau \& Overgaard, 2015; Sidebotham et al., 2015; Dawson et al., 2016) has highlighted the importance of midwives being involved and collaborating in practice change. It is anticipated that this survey will begin to engage midwives in the change process and also help to identify some of the potential challenges. During the post-implementation evaluation it would be relevant to find out if participation in this survey did have any influence on midwives' sense of control and involvement in the change process.

\section{Conclusion}

Using the principles of realist evaluation key programme theories have been identified to inform an evaluation framework to assess the implementation of a midwife-led continuity of carer model. The significant service reorganisation required to successfully implement and sustain a continuity of carer model in midwifery practice requires staff involvement and ongoing evaluation of progress and impact. The comprehensive survey-tool developed for this health services has the potential to be used more widely to evaluate comparable strategic change in this area.

\section{REFERENCES}

Beaumont, E., Durkin, M., Hollins Martin, C. J. and Carson, J. (2016) 'Compassion for others, self-compassion, quality of life and mental well-being measures and their association with compassion fatigue and burnout in student midwives: A quantitative survey', Midwifery, 34(Supplement C), 239-244. 
Burau, V. and Overgaard, C. (2015) 'Caseload midwifery as organisational change: the interplay between professional and organisational projects in Denmark', BMC Pregnancy And Childbirth, 15(1), 121.

Collins, C. T., Fereday, J., Pincombe, J., Oster, C. and Turnbull, D. (2010) 'An evaluation of the satisfaction of midwives' working in midwifery group practice', Midwifery, 26(4), 435-441.

Dalkin, S.M., Greenhalgh, J., Jones, D., Cunningham, B. and Lhussier, M., (2015). What's in a mechanism? Development of a key concept in realist evaluation. Implementation Science, 10(1), 49.

Dawson, K., McLachlan, H., Newton, M. and Forster, D. (2016) 'Implementing caseload midwifery: Exploring the views of maternity managers in Australia - A national crosssectional survey', Women And Birth: Journal Of The Australian College Of Midwives, 29(3), 214-222.

Dixon, L., Guilliland, K., Pallant, J., Sidebotham, M., Fenwick, J., McAra-Couper, J. Gilkison, A. (2017) 'The emotional wellbeing of New Zealand midwives: Comparing responses for midwives in caseloading and shift work settings', New Zealand College of Midwives Journal, (53), 9.

Fenwick, J., Sidebotham, M., Gamble, J. and Creedy, D. K. (2017) 'The emotional and professional wellbeing of Australian midwives: A comparison between those providing continuity of midwifery care and those not providing continuity', Women and Birth. 31(1):38-43. doi: 10.1016/j.wombi.2017.06.013

Fereday, J. and Oster, C. (2010) 'Managing a work-life balance: the experiences of midwives working in a group practice setting', Midwifery, 26 (3): 311-8.

Funnell, S.C., Rogers, P.J., 2011. Purposeful Programme Theory: Effective Use of Theories of Change and Logic Models. Jossey-Bass, San Francisco.

Gilkison, A., McAra-Couper, J., Gunn, J., Crowther, S., Hunter, M., Macgregor, D., Hotchin, C. (2015) Midwifery practice arrangements which sustain caseloading Lead Maternity Carer 
midwives in New Zealand. New Zealand College of Midwives Journal 51, 11-16.

http://dx.doi.org/10.12784/nzcomjnl51.2015.2.11-16.

Haines, H. M., Baker, J., \& Marshall, D. (2015). Continuity of midwifery care for rural women through caseload group practice: Delivering for almost 20 years. Australian Journal of Rural Health, 23(6), 339-345. doi:10.1111/ajr.12232.

Haines H, Rubertsson C, Pallant J, Hildingsson I: (2012) Womens' attitudes and beliefs of childbirth and association with birth preference: A comparison of a Swedish and an Australian sample in mid-pregnancy. Midwifery. e850-6. 10.1016/j.midw.2011.09.011.

Haynes, L., Goldacre, B. and Torgerson, D. (2012) Test, learn, adapt: developing public policy with randomised controlled trials. Cabinet Office-Behavioural Insights Team., Cabinet OfficeBehavioural Insights Team. Available: https://www.gov.uk/government/publications/testlearn-adapt-developing-public-policy-with-randomised-controlled-trials [Accessed 26-4-18]

Health and Safety Executive (HSE) (undated) Work Related Stress - the Management Standards. Available: http://www.hse.gov.uk/stress/standards/index.htm [accessed 26-4$18]$.

Hollins Martin, C. J., \& Martin, C. R. (2014). Development and psychometric properties of the Birth Satisfaction Scale-Revised (BSS-R). Midwifery, 30(6), 610-619. doi:10.1016/j.midw.2013.10.006

Homer, C.S.E.; Leap, N., Edwards, N., Sandall, J. (2017) Midwifery continuity of carer in an area of high socio-economic disadvantage in London: A retrospective analysis of Albany Midwifery Practice outcomes using routine data (1997-2009). Midwifery, 48, 1-10.

Jepsen, I., Juul, S., Foureur, M., Sørensen, E. E. and Nøhr, E. A. (2017) 'Is caseload midwifery a healthy work-form? - A survey of burnout among midwives in Denmark', Sexual \& Reproductive Healthcare, 11(Supplement C), 102-106. 
Jepsen, I., Mark, E., Nøhr, E. A., Foureur, M., Sørensen, E. E. (2016). A qualitative study of how caselaod midwifery is constituted and experienced by Dnish midiwves. Midwifery, 36, 61-69.

Mackenzie, M., Blamey, A., Halliday, E., Maxwell, M., McCollam, A., McDaid, D., MacLean, J., Woodhouse, A. and Platt, S. (2007) 'Measuring the tail of the dog that doesn't bark in the night: the case of the national evaluation of Choose Life (the national strategy and action plan to prevent suicide in Scotland)', BMC Public Health, 7(1), 146.

Matthews, A., Scott, P. A. and Gallagher, P. (2009) 'The development and psychometric evaluation of the Perceptions of Empowerment in Midwifery Scale', Midwifery, 25(3), 327335.

Meadows Report (1998). The Meadows Scheme: Evaluation of a controlled trial of continuity of midwifery care and the assciated community setting. Final Report, September 1998. Published on behalf of the Simpson Maternity Pavillion, Royal Infirmary Edinburgh.

Newton, M. S., McLachlan, H. L., Forster, D. A. and Willis, K. F. (2016) 'Understanding the 'work' of caseload midwives: A mixed-methods exploration of two caseload midwifery models in Victoria, Australia', Women And Birth: Journal Of The Australian College Of Midwives, 29(3), 223-233.

NHS England Better Births (2017) BETTER BIRTHS Improving outcomes of maternity services in England A Five Year Forward View for maternity care https://www.england.nhs.uk/mattransformation/implementing-better-births/[Accessed 26-4-18]

NHS Scotland (2006) 'The Warwick-Edinburgh Mental Well-being Scale (WEMWBS)'. Available at http://www.healthscotland.scot/tools-and-resources/wemwbs [accessed 26-418]

NHS Scotland (2017) 'Improve policy and practice', available: http://www.healthscotland.scot/improve-policy-and-practice/monitor-progress-andevaluate [accessed 26-4-18] 
Pallant, J. F., Dixon, L., Sidebotham, M. and Fenwick, J. (2015) 'Further validation of the perceptions of empowerment in midwifery scale', Midwifery, 31(10), 941-945.

Pawson R., and Tilley N., 1997. Realistic Evaluation. Sage Publications Ltd: London.

Perdok, H., Verhoeven, C. J., van Dillen, J., Schuitmaker, T. J., Hoogendoorn, K., Colli, J., ... de Jonge, A. (2018). Continuity of care is an important and distinct aspect of childbirth experience: findings of a survey evaluating experienced continuity of care, experienced quality of care and women's perception of labor.BMC Pregnancy and Childbirth,18, 13. http://doi.org/10.1186/s12884-017-1615-y

Porter, S., (2015). Realist evaluation: an immanent critique. Nursing Philosophy, 16(4), 239251.

Reime, B., Klein, M., Kelly, A., Duxbury, N., Saxell, L., Liston, R. and et al. (2004) 'Do maternity care provider groups have different attitudes towards birth?', BJOG: An International Journal Of Obstetrics And Gynaecology, 111 (12). 1388-93

Renfrew, M. J., McFadden, A., Bastos, M. H., Campbell, J., Channon, A. A., Cheung, N. F., Silva, D. R., Downe, S., Kennedy, H. P., Malata, A., McCormick, F., Wick, L. and Declercq, E. (2014) 'Midwifery and quality care: findings from a new evidence-informed framework for maternal and newborn care', Lancet, 384.

Royal College of Midwives (2016) Caring for You Campaign: Survey Results, UK: Royal college of Midwives. Available: https://www.rcm.org.uk/caring-for-you-campaign [accessed 26-418]

Sandall, J., Soltani, H., Gates, S., Shennan, A. and Devane, D. (2016a) 'Midwife-led continuity models versus other models of care for childbearing women', Cochrane Database Syst Rev, 4, CD004667.

Sandall, J., Coxon, K., Mackintosh, N., Rayment-Jones, H., Locock, L. and Page, L. (writing on behalf of the Sheila Kitzinger symposium) (2016b) Relationships: the pathway to safe, highquality maternity care Report from the Sheila Kitzinger symposium at Green Templeton College October 2015. Green Templeton College, Oxford. 
Scottish Government (2017) The Best Start: A Five-Year Forward Plan for Maternity and Neonatal Care in Scotland. Available: http://www.gov.scot/Publications/2017/01/3303 [accessed 26-4-18]

Sidebotham, M., Fenwick, J., Rath, S. and Gamble, J. (2015) 'Midwives' perceptions of their role within the context of maternity service reform: An Appreciative Inquiry', Women And Birth: Journal Of The Australian College Of Midwives, 28(2), 112-120.

Stamm, B. H. (2009) 'ProQoL:Compassion Satisfaction and Compassion Fatigue, Burnout, Secondary Traumatic Stress.' Available: http://www.proqol.org [Accessed 26-4-18]

Stevens, T. and McCourt, C. (2002) 'One-to-one midwifery practice part 4: sustaining the model', British Journal of Midwifery, 10(3), 6.

Thomas, J. and Paranjothy, S. (2001) National Sentinel Caesarean Section Audit Report. , Royal College of Obstetricians and Gynaecologists Clinical Effectiveness Support Unit.

Todd, C. J., Farquhar, M. C. and Camilleri-Ferrante, C. (1998) 'Team midwifery: The views and job satisfaction of midwives', Midwifery, 14(4), 214-224.

Turnbull, D., Reid, M., McGinley, M. and Sheilds, N. R. (1995) 'Changes in midwives' attitudes to their professional role following the implementation of the midwifery development unit', Midwifery, 11(3):110-9.

Yoshida, Y. and Sandall, J. (2013) 'Occupational burnout and work factors in community and hospital midwives: a survey analysis', Midwifery, 29 (8):921-6

Young, C. M., Smythe, L., \& Couper, J. M. (2015). Burnout: Lessons From the Lived Experience of Case Loading Midwives. International Journal of Childbirth, 5(3), 154-165. doi:10.1891/2156-5287.5.3.154 
Table 1: 'Conjectured' Context, Mechanism and Outcome (CMO) Configurations for implementation of MLCC model.

\begin{tabular}{|c|c|c|}
\hline CONTEXT & MECHANISMS & OUTCOMES* \\
\hline $\begin{array}{l}\text { Women's experience } \\
\text { - } \quad \text { Fragmentation of maternity care: } \\
\text { - } \quad \text { Multiple care providers care locations } \\
\text { - Inclationship with 'their' midwife } \\
\text { - Increasing intervention during pregnancy and } \\
\text { Midwives' experience } \\
\text { - } \quad \text { Practice according to location rather than } \\
\text { using full range of midwifery skills } \\
\text { - Heavy and increasing workload } \\
\text { - High levels of stress } \\
\text { National operational context } \\
\text { - Recruitment and retention issues } \\
\text { Midwives lack time to attend training, up- } \\
\text { dating or professional development events } \\
\text { Poor relationships between professional } \\
\text { groups (e.g. midwives in different locations; } \\
\text { midwives and others in multi-disciplinary } \\
\text { team(MDT)) }\end{array}$ & $\begin{array}{l}\text { Resources } \\
\text { - Training to ensure competency and skills for } \\
\text { all settings and across antenatal, } \\
\text { intrapartum, post-natal and community care } \\
\text { - Workforce and skill mix to ensure case-load } \\
\text { size ( } 1 \text { midwife: } 35 \text { women/ max } 40 \text { per year) } \\
\text { - MCC model (e.g. 1:1 care; } 1 \text { plus buddy; } \\
\text { small team (midwifery group practice); } \\
\text { buddy system (e.g. within team, between } \\
\text { teams or between different settings (e.g. } \\
\text { community buddied with hospital)) } \\
\text { - Midwifery skills to work across different } \\
\text { settings (community and hospital) and all } \\
\text { - } \text { stages of pregnancy } \\
\text { - } \quad \text { Facilities and space to practice } \\
\text { - Local leadership and support } \\
\text { - Communication and publicity to pregnant } \\
\text { women and the public } \\
\text { Reasoning } \\
\text { - Building of trust between women and } \\
\text { - } \text { midwives } \\
\text { - } \text { Muilding of trust within the MDT } \\
\text { - holistic care }\end{array}$ & $\begin{array}{l}\text { Women-centred care } \\
\text { - } \quad \text { number of midwives involved in all } \\
\text { - } \quad \text { known midwife in attendance at } \\
\text { birth } \\
\text { - Support for women's choices } \\
\text { - } \quad \text { making } \\
\text { - Communication and trust } \\
\text { - Increase in spontaneous vaginal delivery } \\
\text { - } \text { Reduction in interventions } \\
\text { - } \quad \text { Induction of labour } \\
\text { - Forceps/ventouse delivery } \\
\text { - Optimal biosychosocial outcomes } \\
\text { - Positive experience of care } \\
\text { Maternal and baby outcomes } \\
\text { - Improved clinical outcomes } \\
\text { - Reduced preterm birth } \\
\text { - Reduced still birth } \\
\text { - Increase in breastfeeding at birth } \\
\text { Midwives } \\
\text { - Proportion of midwives who carry } \\
\text { - } \text { recommended caseload } \\
\text { - Enhancelopment of midwifery skills } \\
\text { Enhob satisfaction }\end{array}$ \\
\hline
\end{tabular}




\begin{tabular}{|c|c|c|}
\hline $\begin{array}{l}\text { - worked for a small group of women } \\
\text { - increased stress and burnout for } \\
\text { midwives challenges with retention } \\
\text { and recruitment (Meadows Report) } \\
\text { - Evidence of resistance to change and/or } \\
\text { remodelling midwifery }\end{array}$ & $\begin{array}{l}\text { - Women and public's acceptance of new } \\
\text { model }\end{array}$ & $\begin{array}{l}\text { - Sense of empowerment to deliver best } \\
\text { - } \text { Inidwifery care } \\
\text { Organisational } \\
\text { - Improved inter-professional relationships } \\
\text { - Improved retention } \\
\text { - } \quad \text { Reduction in sickness absence } \\
\text { - Improved reputation } \\
\text { - Reduction in adverse incidents } \\
\text { - } \quad \text { Reduction in complaints }\end{array}$ \\
\hline
\end{tabular}


Table 2: Evaluation Framework: clinical outcomes, women and midwives

\begin{tabular}{|c|c|c|c|c|}
\hline $\begin{array}{l}\text { Recommended Care } \\
\text { Domains of high quality midwifery care } \\
\text { (Renfrew et al. 2014) } \\
\text { Best Start Strategy (Scottish Government } \\
\text { 2017) \& other research }\end{array}$ & Questions/process and outcomes & Tools or measures & Data Collection Process & Hypothesis - new model will result in: \\
\hline \multicolumn{5}{|l|}{ Practice - what care is provided } \\
\hline $\begin{array}{l}\text { Good quality midwifery practice includes } \\
\text { education, information \& health } \\
\text { promotion, assessment, screening and } \\
\text { care planning. It will aim to promote } \\
\text { normal processes and prevent } \\
\text { complications. }\end{array}$ & $\begin{array}{l}\text { Uptake of classes; booking gestation, } \\
\text { screening tests; clinical processes \& } \\
\text { outcomes (pregnancy, birth \& PN) }\end{array}$ & Routine clinical data & $\begin{array}{l}\text { Routine data: ongoing } \\
\text { to be summarized } \\
\text { annually }\end{array}$ & $\begin{array}{l}\text { Increase in physiological pregnancies, } \\
\text { labour and births - see Table } 1 \text { for } \\
\text { details } \\
\text { Reduction in interventions - see Table } 1 \\
\text { Better outcomes for mother and baby }\end{array}$ \\
\hline $\begin{array}{l}\text { Women with complex needs will receive } \\
\text { high quality care from the wider } \\
\text { multidisciplinary care team with timely } \\
\text { referral processes. }\end{array}$ & $\begin{array}{l}\text { Referral or transfer to other services } \\
\text { (including triage) }\end{array}$ & Routine clinical data & $\begin{array}{l}\text { Routine data: ongoing - } \\
\text { summarized annually }\end{array}$ & $\begin{array}{l}\text { Increase in timely and appropriate } \\
\text { referral }\end{array}$ \\
\hline \multicolumn{5}{|l|}{ Care organization and care providers } \\
\hline \multirow{4}{*}{$\begin{array}{l}\text { Midwifery care is properly resourced, } \\
\text { available, accessible and acceptable to } \\
\text { women, with services integrated in the } \\
\text { community; woman centred \& organized } \\
\text { in community hubs. }\end{array}$} & $\begin{array}{l}\text { Where are midwives located? } \\
\text { What resources do midwives need for the } \\
\text { model? }\end{array}$ & $\begin{array}{l}\text { Scope MW location and travel } \\
\text { Open question in MW survey } \\
\text { tool }\end{array}$ & Midwives' survey & $\begin{array}{l}\text { Increased number of MWs located in } \\
\text { community } \\
\text { MW feel properly resourced to provide } \\
\text { MLCC }\end{array}$ \\
\hline & Do women experience available \& & Care Measure Scale ${ }^{1}$ & $\begin{array}{l}\text { Women's survey } \\
\text { completed AN \& PN }\end{array}$ & \multirow{2}{*}{$\begin{array}{l}\text { Increased Satisfaction with care } \\
\text { Increased birth satisfaction }\end{array}$} \\
\hline & acceptable midwifery care? & $\begin{array}{l}\text { Birth Satisfaction Scale (Hollins } \\
\text { Martin et al., 2014) }\end{array}$ & $\begin{array}{l}\text { Women's survey } \\
\text { completed PN }\end{array}$ & \\
\hline & $\begin{array}{l}\text { Is accessible care provided in the } \\
\text { community? }\end{array}$ & $\begin{array}{l}\text { Ask women where care was } \\
\text { provided }\end{array}$ & $\begin{array}{l}\text { Women's survey } \\
\text { completed AN \& PN }\end{array}$ & $\begin{array}{l}\text { Increase in midwifery care provided in } \\
\text { the home and the community }\end{array}$ \\
\hline \multirow{5}{*}{$\begin{array}{l}\text { Midwife Led Continuity of Carer (MLCC) is } \\
\text { the recommended model and the SG } \\
\text { strategy (2017) advocates a Primary } \\
\text { midwife working with a buddy (caseload } \\
\text { model) for ALL women } \\
\text { Important to evaluate and detail type of } \\
\text { continuity model adopted (Sandall et al. } \\
\text { 2016). }\end{array}$} & What is level of MLCC and $1: 1$ care? & $\begin{array}{l}\text { Routine clinical Data -continuity } \\
\text { by team, risk and outcomes }\end{array}$ & Routine Data & \multirow{2}{*}{$\begin{array}{l}\text { Increase in women receiving AN \& all } \\
\text { care from } 2 \text { midwives; } \\
\text { Increase in number of women being } \\
\text { cared for at birth by a known midwife }\end{array}$} \\
\hline & & $\begin{array}{l}\text { NCQ continuity scale (Perdok et } \\
\text { al., 2018) }\end{array}$ & $\begin{array}{l}\text { Women's survey AN \& } \\
\text { PN }\end{array}$ & \\
\hline & What are midwives experiences of MLCC? & $\begin{array}{l}\text { MLCC experience \& } \\
\text { preferences - survey tool }\end{array}$ & Midwives' survey & $\begin{array}{l}\text { Increase no of midwives working in } \\
\text { MLCC }\end{array}$ \\
\hline & What do midwives think about MLCC? & Open Question - free text & Midwives' survey & $\begin{array}{l}\text { [Opportunity to explore what MW think } \\
\text { about MLCC] }\end{array}$ \\
\hline & What are midwives attitudes to MLCC? & Continuity statements ${ }^{2}$ & Midwives' survey & More positive attitude to MLCC \\
\hline
\end{tabular}




\begin{tabular}{|c|c|c|c|c|}
\hline & $\begin{array}{l}\text { What are women's experiences of MLCC? } \\
\text { What does continuity mean for women? }\end{array}$ & Open Question & $\begin{array}{l}\text { Women's survey AN \& } \\
\text { PN }\end{array}$ & $\begin{array}{l}\text { [opportunity to explore the meaning } \\
\text { and experience of continuity of carer } \\
\text { from women's perspective] }\end{array}$ \\
\hline \multirow{3}{*}{$\begin{array}{l}\text { Care providers are clinically competent } \\
\text { with good interpersonal skills. }\end{array}$} & $\begin{array}{l}\text { Do different models of care affect midwives' } \\
\text { compassion scores? }\end{array}$ & $\begin{array}{l}\text { Professional Quality of Life } \\
\text { (ProQoL) Scale (Stamm, 2009) }\end{array}$ & \multirow{3}{*}{ Midwives' survey } & $\begin{array}{l}\text { Higher/more positive compassion } \\
\text { scores in new model }\end{array}$ \\
\hline & What are MWs training needs? & Open Question & & MW feel skilled to provide care \\
\hline & Clinical competence & Routine clinical data & & Quality of care and adverse events \\
\hline \multicolumn{5}{|c|}{ Philosophy and Values (including qualities of respectful care) } \\
\hline \multirow{3}{*}{$\begin{array}{l}\text { Respect, communication, community } \\
\text { knowledge \& understanding with care } \\
\text { tailored to circumstances and need. It also } \\
\text { includes empathy being treated with } \\
\text { dignity and being listened and responded } \\
\text { to (Sandall et al. 2016; RCM, 2016). } \\
\text { Women, families and care providers. } \\
\text { A respectful workplace includes: } \\
\text { interpersonal relations within the } \\
\text { midwifery and wider MDT. A sense of } \\
\text { control is a key element and is linked to } \\
\text { reduced levels of stress. High levels of } \\
\text { workplace stress, burn out and concerns } \\
\text { about ability to provide high quality care in } \\
\text { current practice (RCM, 2016). }\end{array}$} & $\begin{array}{l}\text { Are midwives satisfied with their role? } \\
\text { Do midwives feel positive about their role \& } \\
\text { their organisation? } \\
\text { Do midwives feel empowered? } \\
\text { Are midwives burnt-out \& stressed? } \\
\text { Do midwives have good mental wellbeing? }\end{array}$ & $\begin{array}{l}\text { Attitude to Midwifery Role } \\
\text { Scale (Turnbull et al., 1995) } \\
\text { Role \& organisation statements } \\
\text { (RCM, 2016) } \\
\text { Perceptions of empowerment } \\
\text { (Matthews et al., 2009, Pallant } \\
\text { et al., 2015) } \\
\text { ProQoL Scale (Stamm, 2009) } \\
\text { Short Warwick-Edinburgh } \\
\text { Mental Health Scale (NHS } \\
\text { Scotland 2006) }\end{array}$ & Midwives' survey & $\begin{array}{l}\text { More positive attitude to midwifery } \\
\text { role. } \\
\text { More positive attitude to midwifery role } \\
\text { and to their organisation } \\
\text { MW feel empowered to work } \\
\text { autonomously } \\
\text { Reduced burnout and secondary } \\
\text { traumatic stress } \\
\text { Improved midwife wellbeing }\end{array}$ \\
\hline & \multirow[t]{2}{*}{$\begin{array}{l}\text { Do women feel listened to? } \\
\text { Are they involved in their care and care } \\
\text { decisions? } \\
\text { Are they satisfied with their care? }\end{array}$} & $\begin{array}{l}\text { Shared Decision Making \& } \\
\text { confidence in care providers } \\
\text { Scale }^{3}\end{array}$ & $\begin{array}{l}\text { Women's survey AN \& } \\
\text { PN }\end{array}$ & \multirow[t]{2}{*}{$\begin{array}{l}\text { Increase in shared decision making } \\
\text { Women feel listened to - } \\
\text { Satisfied with care (AN, IP, PN) }\end{array}$} \\
\hline & & $\begin{array}{l}\text { Birth satisfaction scale (Hollins } \\
\text { Martin et al., 2014) }\end{array}$ & Women's survey PN & \\
\hline $\begin{array}{l}\text { Underpinning philosophy of holistic care } \\
\text { which optimizes biopsychosocial \& cultural } \\
\text { processes and strengthens women's } \\
\text { capabilities }\end{array}$ & $\begin{array}{l}\text { What are midwives attitudes to normality } \\
\text { and intervention? }\end{array}$ & $\begin{array}{l}\text { Birth Attitude Scale (Reime et } \\
\text { al., 2004) } \\
\text { Birth choice questions (Thomas } \\
\text { and Paranjothy, 2001) }\end{array}$ & Midwives' survey & $\begin{array}{l}\text { Change in dominance from medical } \\
\text { model to holistic model: increase in pro- } \\
\text { normality }\end{array}$ \\
\hline
\end{tabular}




\begin{tabular}{|l|l|}
\hline & $\begin{array}{l}\text { What are women's attitudes to birth and } \\
\text { pregnancy? }\end{array}$ \\
\hline
\end{tabular}

Birth Attitudes Profile Scale

(BAPS) (Haines et al., 2012)

Birth choice questions (Thomas

Women's survey AN

Mothers will report an increase in

and Paranjothy 2001)

positive attitudes towards pregnancy

and birth as a normal physiological

Care Measure Scale (http://www.caremeasure.org/index.php)

2. Continuity statements - developed from stakeholder interviews, published literature and informal interviews

3. Shared Decision Making \& confidence in care providers Scale Healthcare Responsiveness scale (4 Questions from ICHOM: http://www.ichom.org/medical-conditions/pregnancyand-childbirth/) plus a question (CARESAT1: how satisfied are you with the results of your care .......during pregnancy/during labour and birth/after your baby was born 